\title{
Study on Oxidation of Benzhydrol and P-Chlorobenzhydrol by Selenium Dioxide: Reaction Kinetics
}

\author{
Durgesh Kumar Dwivedi ${ }^{1}$, Arvind Prasad Dwivedi ${ }^{2}$, Nagmani Manikpuri ${ }^{3}$ \\ ${ }^{1}$ Post Graduate Department of Chemistry, Pt. S.N.S. Govt. P.G. (Autonomous) College (NACC), Shahdol (M.P.) \\ India \\ ${ }^{2}$ Department of Chemistry, Govt. Sanjay Gandhi Smrati Auto., P.G., College Sidhi M.P. \\ ${ }^{3}$ Department of Chemistry, Govt. Nehrru P.G. College (NAAC) Burhar, District Shahdol (M.P.) India.
}

*Corresponding Author: Durgesh Kumar Dwivedi, Post Graduate Department of Chemistry, Pt. S.N.S. Govt. P.G. (Autonomous) College (NACC), Shahdol (M.P.) India

\begin{abstract}
The oxidation kinetics of benzhydrol and para-chlorobenzhydrol involving rare earth compound selenium dioxide as an oxidant in acetic acid-water medium in presence of $\mathrm{H}_{2} \mathrm{SO}_{4}$ have been studied in order to probe better reaction mechanism. The reactions obey first-order kinetics in [SeO $\mathrm{O}_{2}$ ] and [substrate] and sensitized to $\mathrm{H}^{+}$ions. The ionic strength on rate of reaction has nominal effect. An increase in rate with increasing percentage of solvent was observed. I and + mesomeric effects dominate the order of reactivity in conformity with Arrhenius parameters.
\end{abstract}

Keywords: Selenium dioxide, probe, kinetics, oxidation, benzhydrol.

\section{INTRODUCTION}

It is known from a long time that rare earths compound viz. Selenium dioxide $\left(\mathrm{SeO}_{2}\right)$, Selenious and Selenic acids as well as selenites are readily reduced by a variety of substances to selenium but their oxidizing properties were not studies systematically. Riley, Morley and Friend ${ }^{1}$ were the first pioneer to introduce the potential of $\mathrm{SeO}_{2}$ as an oxidant, since then considerable progress has been made for the oxidation of a large number of organic compounds. ${ }^{2}$ In presence of strong mineral acids such as $\mathrm{H}_{2} \mathrm{SO}_{4}$, it gives rise existing active oxidizing species $\mathrm{H}_{3} \mathrm{SeO}_{3}{ }^{+}$or $\mathrm{AcH}_{3} \mathrm{SeO}_{3}$ to cause the reaction.

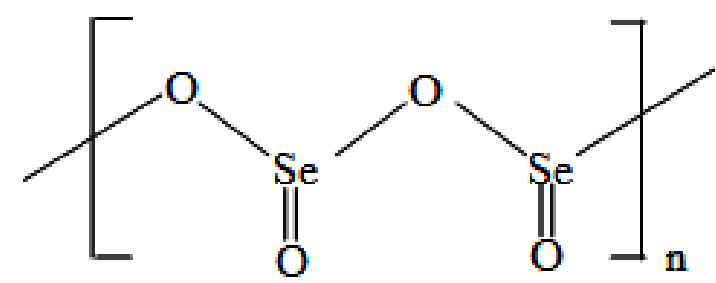

$\mathrm{SeO}_{2}$ most commonly oxidizes $\mathrm{C}-\mathrm{H}$ bonds linked to various activating groups like, olefins, - $\mathrm{CHO}$, -C$\mathrm{HO}$, - $\mathrm{COOH}$ etc. The oxidant $\mathrm{SeO}_{2}$ has been employed in the oxidation kinetics of ketones ${ }^{3-7}$, alcohols, ${ }^{\mathbf{8}}$ aldehydes ${ }^{9}$, acids 10 etc.

Benzhydrol is actually bulky, secondary aromatic alcohol in which hydroxyl- group $(-\mathrm{OH})$ is directly attached to the secondary carbon atom, exhibit a variety of chemical reactions. The elucidation of mechanism becomes more interesting when $-\mathrm{Cl}$ group is introduced in para-position of benzhydrol showing negative inductive, + mesomeric, and steric effects.

The above parameters are responsible for accountability of structure and reactivity of substrates. The recent surveys of literature pertaining to the work of oxidation of benzhydrol and p-substituted benzhydrols have been reported by different oxidizing agents namely. N-bromosuccinimide (NBS) ${ }^{\mathbf{1 1}}$, NBP catalysed by PTA ${ }^{12}$, tricaprylmethyl ammoniumchloride ${ }^{13}, \mathrm{KMnO}_{4}{ }^{14}$, t-butylhydroperoxide (TBH $)^{15}$ etc. From the above survey, it is felt worthwhile to study the unreported kinetics of oxidation of benzhydrol and P-chlorobenzhydrol by $\mathrm{SeO}_{2}$. 


\section{EXPERIMENTAL}

The oxidant $\mathrm{SeO}_{2}$ (Loba) and acetic acid (B.D.H. grade) was used as such without purification. The substrates benzhydrol and p-chlorobenzhydrols were used of branded firms. All the necessary solutions of different reagents, participating in reactions were prepared in doubly distilled water, and standardized properly as per methods described in literature. The solution of $\mathrm{H}_{2} \mathrm{SO}_{4}$ was prepared in distilled water and its strength was checked by standard $\mathrm{NaOH}$, solution which was standardized in turn by solution of oxalic acid using phenolphthalein as an indicator.

\subsection{Kinetic Procedure}

The kinetic study of the reactions were carried out under the pseudo first-order conditions $\left[\mathrm{SeO}_{2}\right]<<$ [substrate] by the method of initial velocities. The oxidation reactions were performed in a corning glass reaction vessel with a variable speed stirrer and thermo regulated cell. The temperature of water was regulated with a precision of $\pm 0.1^{\circ} \mathrm{C}$ in thermostat. Requisite quantity of solution of oxidant $\left(\mathrm{SeO}_{2}\right)$ was taken in a separate flask, and kept in a thermostat at experimental temperature. The mixture containing definite calculated amounts of solutions of substrate, acid and water were also taken in another flask equilibrated at $308 \mathrm{~K}$ for 45 minutes. The kinetics followed the reduction reaction by adding specific amount of pre-equilibrated oxidant solution of selenium dioxide.

The progress of reaction was monitored by withdrawing $2 \mathrm{ml}$ aliquots of reaction mixture at regular time of intervals iodometrically using hypo and $1 \%$ solution of starch as an indicator. ${ }^{16}$ Each titre value fed to integration and least square methods to evaluate reaction velocity constant $(\mathrm{k})$. The duplicate kinetic runs indicated that the velocity constants were reproducible to within $\pm 3 \%$. The observed stoichiometry i.e. with a ratio of $\mathrm{SeO}_{2}$ to substrate of $1: 2$ was ascertained:

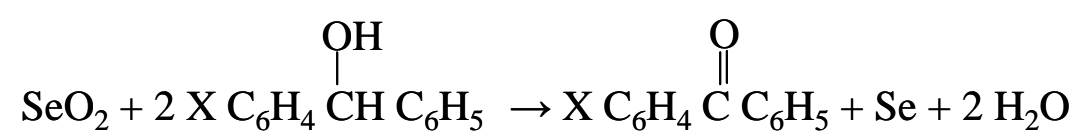

The completion of the oxidation reaction afforded good yield (above 79\%) of benzophenone and pchlorobenzophenone as the main end-products, which was characterized by chemical and spectral methods and also by forming 2,4-DNP derivatives.

\section{RESULTS AND DISCUSSION}

\subsection{Order of Reactants}

The dependence of the initial velocity (-dx/dt) expressed as the cost of consumption of different concentrations of oxidant $\left(\mathrm{SeO}_{2}\right)$ on the oxidation of benzhydrol and p-chlorobenzhydrol in $30 \%$ $\mathrm{CH}_{3} \mathrm{COOH}$ at $308 \mathrm{~K}$ have been studied. By plotting the log of remaining $\left[\mathrm{SeO}_{2}\right]$ as a function of time was found linear $\left(\mathrm{r}^{2}=0.983\right)$ with unit slope indicated first-order dependence on $\left[\mathrm{SeO}_{2}\right]$. Several sets of experiments with varying concentrations of aforesaid substrates were conducted at $308 \mathrm{~K}$ maintaining the concentrations of reagents $\mathrm{SeO}_{2}, \mathrm{H}_{2} \mathrm{SO}_{4}$, and acetic acid constant. The observed data collected is reported in Table: 1.

Table1. Dependence of the initial velocity constant ( $k$ ) on substrate's concentrations

$\left[\mathrm{SeO}_{2}\right] \times 10^{3}\left(\mathrm{~mol} \mathrm{dm}^{-3}\right)=2.50(1,2) ;$

$\left[H^{+}\right] \times 10^{3}\left(\mathrm{~mol} \mathrm{dm}^{-3}\right)=1.0(1), 1.25(2) ;$

$\mathrm{HOAc}-\mathrm{H}_{2} \mathrm{O}, \%(\mathrm{v} / \mathrm{v})=30(1,2)$;

Temperature $K=308(1,2)$

\begin{tabular}{|c|c|c|c|}
\hline S. No. & $\begin{array}{c}10^{3} \times[\text { Substrate }] \\
\left(\mathrm{mol} \mathrm{dm}^{-3}\right)\end{array}$ & $\begin{array}{c}\text { Benzhydrol } \\
(1)\end{array}$ & $\begin{array}{c}\text { P-chlorobenzhydrol } \\
(2)\end{array}$ \\
\cline { 3 - 4 } & & 0.96 & 0.81 \\
\hline 1. & 1.25 & 1.61 & 1.47 \\
\hline 2. & 2.00 & 2.24 & 2.03 \\
\hline 3. & 2.50 & 2.54 & 2.14 \\
\hline 4. & 3.33 & 3.03 & 2.75 \\
\hline 5. & 4.00 & 3.87 & 3.32 \\
\hline 6. & 5.00 & & $\rightarrow$ \\
\hline
\end{tabular}


Table2. Dependence of initial velocity on the Acid concentrations

$\left[\mathrm{SeO}_{2}\right] \times 10^{3}\left(\mathrm{~mol} \mathrm{dm}^{-3}\right)=2.50(1,2) ;$

[Substrate] $\times 10^{2}\left(\mathrm{~mol} \mathrm{dm}^{-3}\right)=2.50(1,2)$;

$\mathrm{HOAc}-\mathrm{H}_{2} \mathrm{O}, \%(v / v)=30(1,2)$;

Temperature $K=308(1,2)$

\begin{tabular}{|c|c|c|c|}
\hline S. No. & $\begin{array}{c}10^{3} \times\left[\mathrm{H}_{2} \mathrm{SO}_{4}\right] \\
\left(\mathrm{mol} \mathrm{dm}^{-3}\right)\end{array}$ & $\begin{array}{c}\text { Benzhydrol } \\
\mathrm{k}_{1} \times 10^{4}\left(\mathrm{~s}^{-1}\right) \rightarrow\end{array}$ \\
\cline { 3 - 4 } & & $(1)$ & \multicolumn{2}{c|}{$\begin{array}{c}\text { P-chlorobenzhydrol } \\
(2)\end{array}$} \\
\hline 1. & 1.00 & 2.24 & 1.55 \\
\hline 2. & 1.25 & 2.92 & 2.03 \\
\hline 3. & 2.00 & 3.72 & 3.61 \\
\hline 4. & 2.50 & 4.57 & 5.10 \\
\hline 5. & 4.00 & 6.13 & 5.84 \\
\hline 6. & 5.00 & 6.90 & 2.32 \\
\hline
\end{tabular}

The increase in initial reaction rates with rise in concentrations of substrates and their linear plots with nearly unit slope, $\mathrm{k}$ versus [substrate], and $1 / \mathrm{k}$ versus $1 /$ [substrate] clearly demonstrate first-order dependence of rate on [substrate] (Figs. 1, and 2). The study totally negate the formulation of any complex between reacting species of oxidant $\mathrm{H}_{3} \mathrm{SeO}_{3}^{+}$and substrate. The effect of $\mathrm{H}_{2} \mathrm{SO}_{4}$ concentrations ranging from $1.00 \times 10^{-3}$ to $5.00 \times 10^{-3}\left(\mathrm{~mol} \mathrm{dm}^{-3}\right)$ was studied on the rate of reactions while the reagents concentrations were kept constant at $308 \mathrm{~K}$. The initial velocity constant $(\mathrm{k})$ values found to increase in a manner analogous to that described above are shown in (Table:2). Plotting the $\log \mathrm{k}$ values against $\log \left[\mathrm{H}^{+}\right]$as described for the reactions produced a straight line with almost unit slope (0.96) lead towards first-order rate on $\left[\mathrm{H}_{2} \mathrm{SO}_{4}\right]$ (Fig.3). The ionic strength of the medium has shown effect on the reaction, which non-influential negligible may presumably be due to involvement of a neutral molecule in the rate determine step. In the present investigation, the rise in percentage composition of solvent acetic acid (20-50\%) causes increase in rate of reactions and yield a positive slope from the linear plot $^{17}$ of $\log \mathrm{k}$ vs. 1/D (Fig. not shown). The addition of different concentrations of acrylonitrile fails to induce the reactions and non-occurrence of turbidity and inertness shown by reactions completely discarded the presence of free radical inhibitor. The kinetic study was conducted for the afore mentioned oxidation reactions at four different temperatures $\left(30,35,40\right.$ and $\left.45^{\circ} \mathrm{C}\right)$ with $\mathrm{SeO}_{2}$ of concentration $2.50 \times 10^{-3}\left(\mathrm{~mol} \mathrm{dm}^{-3}\right)$ in a solution of $1.0 \times 10^{-3}\left(\mathrm{~mol} \mathrm{dm}{ }^{-3}\right) \mathrm{H}_{2} \mathrm{SO}_{4}$ and $30 \%$ $\mathrm{CH}_{3} \mathrm{COOH}$. The results are recorded in Table: 3 .

Table3. Activation and Thermodynamic parameters of benzhydrol, p-chlorobenzhydrol-Se $\mathrm{O}_{2}$ system

$\left[\mathrm{SeO}_{2}\right] \times 10^{3}\left(\mathrm{~mol} \mathrm{dm}^{-3}\right)=2.50(1,2)$;

[Substrate] $\times 10^{2}\left(\mathrm{~mol} \mathrm{dm}^{-3}\right)=2.50(1,2) ;$

$\left[\mathrm{H}^{+}\right] \times 10^{3}\left(\mathrm{~mol} \mathrm{dm}^{-3}\right)=1.0(1), 1.25(2) ;$

HOAc- $\mathrm{H}_{2} \mathrm{O}, \%(\mathrm{v} / \mathrm{v})=30(1,2)$

\begin{tabular}{|c|c|c|c|}
\hline $\begin{array}{c}\text { S. } \\
\text { No. }\end{array}$ & $\begin{array}{c}\text { Activation and Thermodynamic } \\
\text { parameters }\end{array}$ & $\begin{array}{c}\text { Benzhydrol } \\
(1)\end{array}$ & P-chlorobenzhydrol \\
\hline 1. & $\mathrm{Ea}\left(\mathrm{kJ} \mathrm{mol}^{-1}\right)$ & 34.88 & 36.12 \\
\hline 2. & $\mathrm{~A} \times 10^{2}\left(\mathrm{~s}^{-1}\right)$ & 1.95 & 2.49 \\
\hline 3. & $\Delta \mathrm{H}^{\#}\left(\mathrm{~kJ} \mathrm{~mol}^{-1}\right)$ & 32.56 & 33.00 \\
\hline 4. & $\Delta \mathrm{G}^{\#}\left(\mathrm{~kJ} \mathrm{~mol}^{-1}\right)$ & 88.05 & 88.29 \\
\hline 5. & $-\Delta \mathrm{S}^{\#}\left(\mathrm{JK}^{-1} \mathrm{~mol}^{-1}\right)$ & 178.72 & 177.98 \\
\hline
\end{tabular}




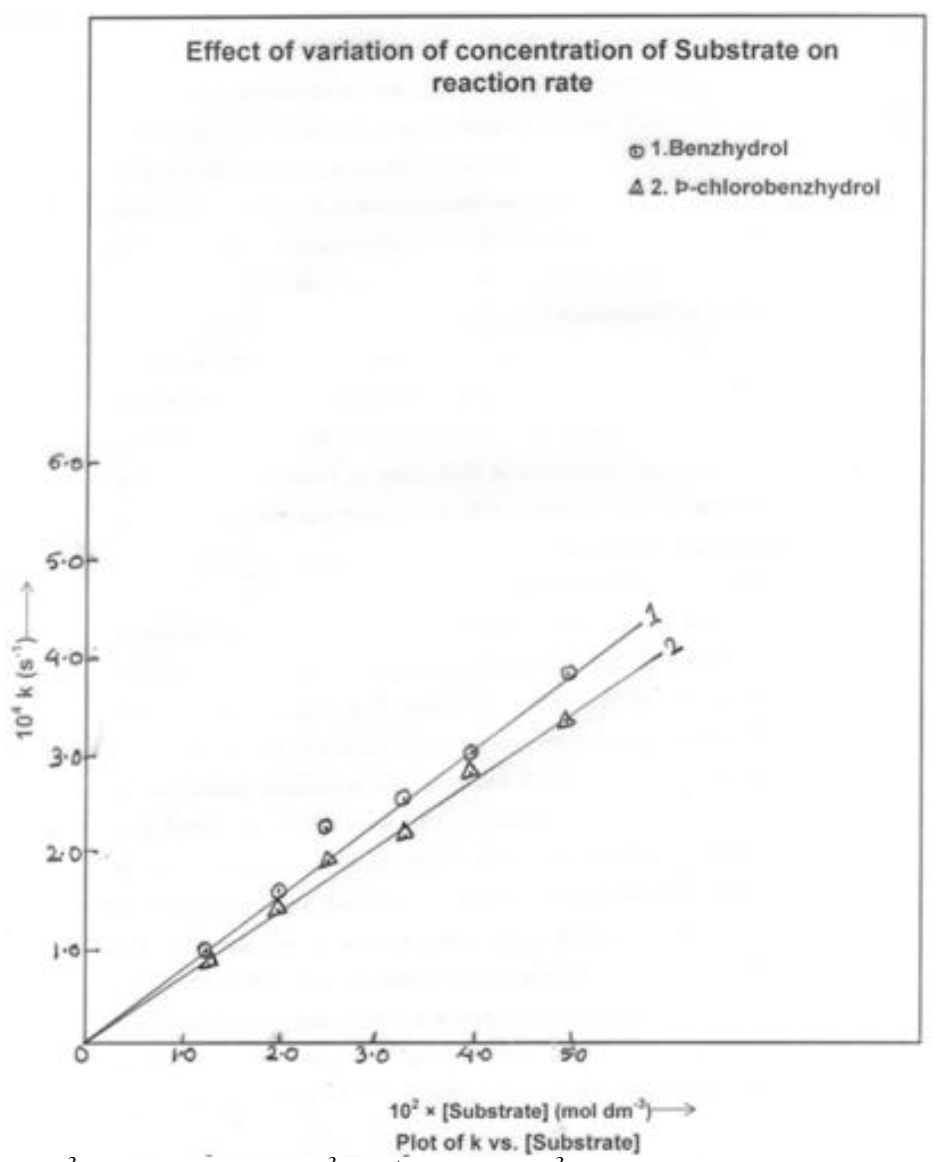

Fig1. $10^{3} x\left[\mathrm{SeO}_{2}\right]\left(\mathrm{mol} \mathrm{dm}^{-3}\right)=2.50(1,2) ; 10^{3} x\left[\mathrm{H}^{+}\right]\left(\mathrm{mol} \mathrm{dm}^{-3}\right)=1.0(1), 1.25(2) ; \mathrm{CH}_{3} \mathrm{COOH}-\mathrm{H}_{2} \mathrm{O} \%,(\mathrm{v} / \mathrm{v})=30$ $(1,2)$; Temp. $K=308(1,2)$

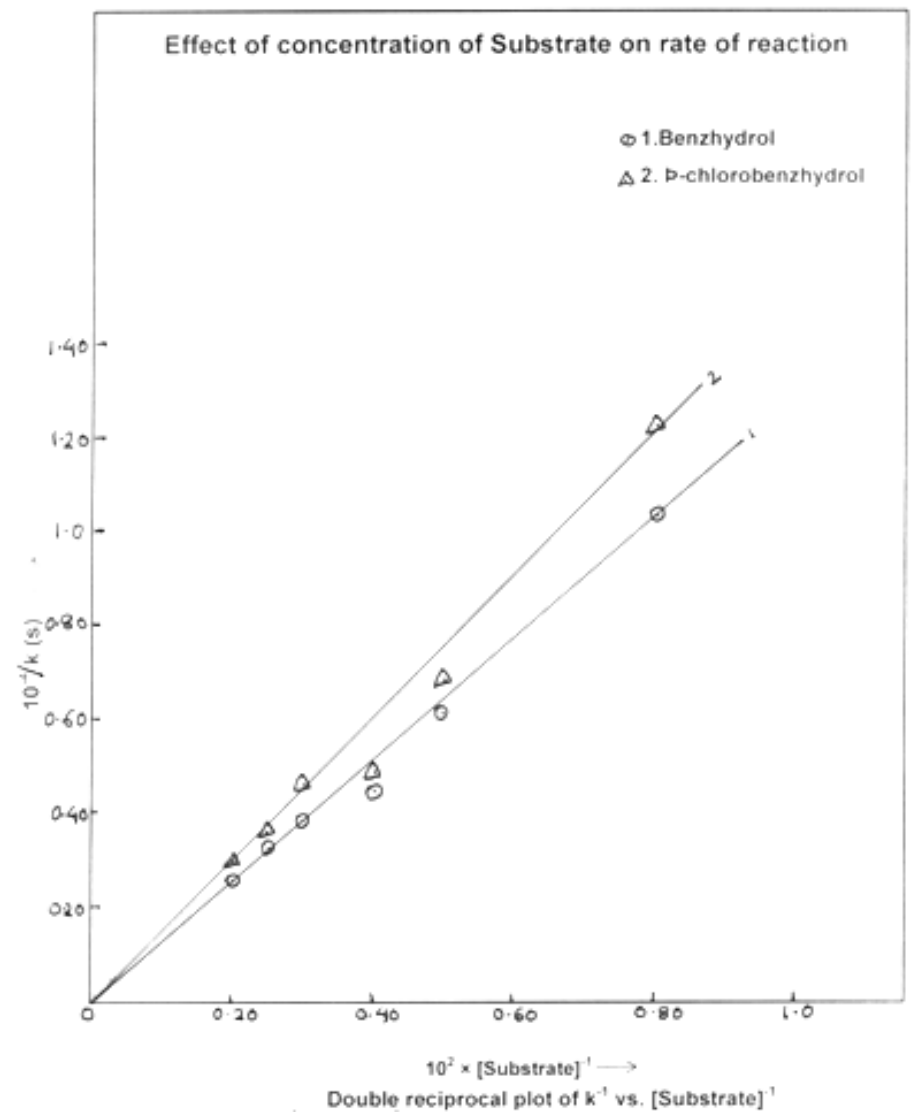

Fig2. $\left[\mathrm{SeO}_{2}\right] \times 10^{3}\left(\mathrm{~mol} \mathrm{dm}^{-3}\right)=2.50(1,2) ;\left[\mathrm{H}^{+}\right] x 10^{3}\left(\mathrm{~mol} \mathrm{dm} \mathrm{m}^{-3}\right)=1.00(1), 1.25(2) ; \mathrm{HOAc}-\mathrm{H}_{2} \mathrm{O} \%(\mathrm{v} / \mathrm{v})=30$ $(1,2) ;$ Temp. $K=308(1,2)$ 


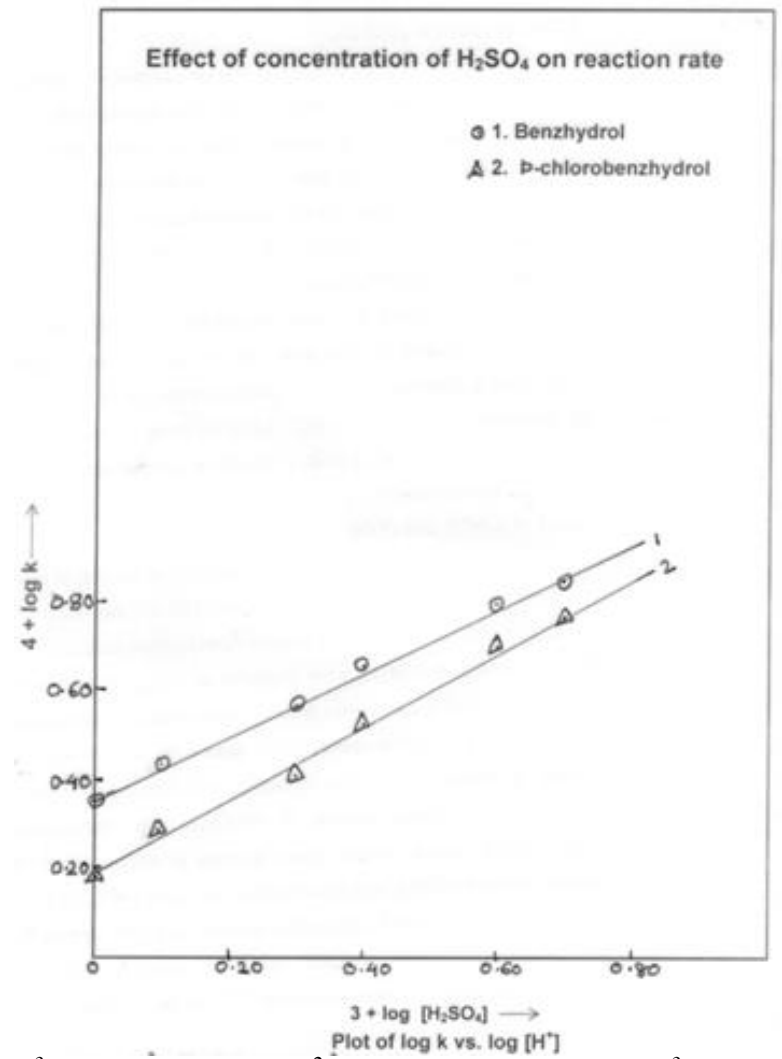

Fig3. $\left.10^{3} \times\left[\mathrm{SeO}_{2}\right](\mathrm{mol} \mathrm{dm})^{-3}\right)=2.50(1,2) ; 10^{2} \times$ [Substrate] $\left(\mathrm{mol} \mathrm{dm}{ }^{-3}\right)=2.50(1,2) ; \mathrm{HOAc}-\mathrm{H}_{2} \mathrm{O} \%(\mathrm{v} / \mathrm{v})$ $=30(1,2) ;$ Temp. $K=308(1,2)$

\subsection{Mechanism}

The dominant species $\mathrm{H}_{3} \mathrm{SeO}_{3}{ }^{+}$of oxidant $\left(\mathrm{SeO}_{2}\right)$ that exists in $\mathrm{H}_{2} \mathrm{SO}_{4}$ has been postulated with the aim of illustrating the redox type mechanism involved in the reactions with several steps predicted are summarized as follows:

$$
\begin{aligned}
& \mathrm{SeO}_{2}+\mathrm{H}_{2} \mathrm{O} \longrightarrow \mathrm{H}_{2} \mathrm{SeO}_{3} \\
& \mathrm{H}_{2} \mathrm{SeO}_{3} \stackrel{+\mathrm{H}^{+}}{\underset{-\mathrm{H}^{+}}{\rightleftharpoons}} \mathrm{H}_{3} \mathrm{SeO}_{3}^{+}
\end{aligned}
$$

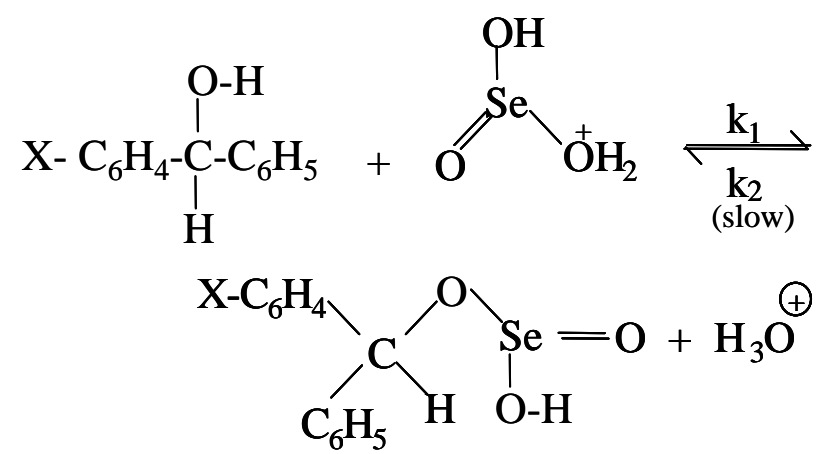

where, $\mathrm{X}=-\mathrm{H}$, and $-\mathrm{Cl}$ respectively.

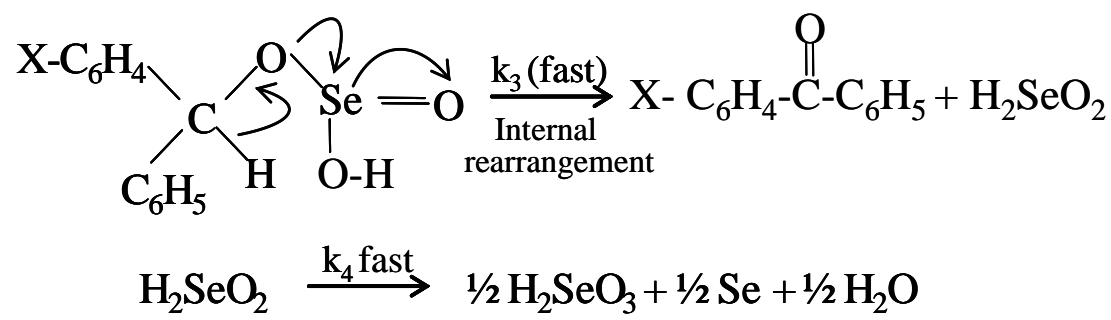


The final rate expression was derived for the illustrated mechanism is of the form :

$$
\text { Rate of reaction } \left.=\mathrm{k}_{1} \text { [substrate }\right]\left[\mathrm{H}_{2} \mathrm{SeO}_{3}\right]\left[\mathrm{H}^{+}\right]
$$

The foregoing scheme of mechanism for the reactions is satisfied by the kinetic equation (7) and other experimental results. The activation entropy $\left(\Delta S^{\#}\right)$ was negative for all the two substrates. The observed $\Delta \mathrm{H}^{\#}$ (enthalpy of activation) and Ea (energy of activation) are of the order of benzhydrol > p-chlorobenzhydrol i.e. the same order of reactivity. The reactivity is well in accordance with the activation parameters evaluated and vis-à-vis dominated by $\sim \mathrm{I}$ and $+\mathrm{M}$ effects. Overall the reactions are demonstrated as enthalpy controlled.

\section{CONCLUSION}

The rate of oxidation of reactions favored a good yield (75-80\%) productive substance benzophenone and p-chlorobenzophenone. The constancy in the values of free energy of activation $\left(\Delta G^{\#}\right)$ calculated indicate that identical kind of mechanism could be operative for the reactions. The reactions follow observed stoichiometry. The mechanism involves the attack of $\mathrm{H}_{3} \mathrm{SeO}_{3}^{+}$reacting species at the reaction site, explained based on $-\mathrm{I}$, and $+\mathrm{M}$ concepts.

\section{REFERENCES}

[1] Riley, H.L., Morley, L.F. and Friend, A.C., J. Chem. Soc., 1932, 2342.

[2] Rabjohn, N., Organic Reactions Vol. 5, John Willey and Sons, Inc., NewYork, 1959, Chap. 8.

[3] Schaefer, J.P., J. Amer. Chem. Soc., 1962, 84, 713.

[4] Singh, K.J. and Anand, S.N., J. Indian Chem. Soc., 1979, 56, 363.

[5] Valechha, N.D. and Pradhan, A., J. Indian Chem. Soc., 1984, 61, 495.

[6] Tiwari, Sanjay, Khan, M.U., and Valechha, N.D., Oxid. Commun. 1999, 22, No.3, 424-431.

[7] Scok Kim-Hong, Ho Kang-Jung, Bull. Korcan, Chem. Soc., 2002, Vol. 22, No.12, 1390.

[8] Valechha, N.D. and Pandey, A., J. Indian Chem. Soc., 1986, 62.

[9] Khan, M.U., Valechha, N.D., Verma, J.K. and Singh, V.R.,Oxid. Commun, 18, No. 3, 312-320, (1995).

[10] Singh, S.K., Gupta, O.P., Khan, M.U., Gupta, H.D. and Singh, P.K., Oxid. Commun. 2011, 34, No.1, 5864.

[11] Hiran, B.L., Malkani, R.K. and Rathore, N., Kinetics and Catalysis 2005, Vol. 46, No.3, 334-339.

[12] Bharad Jagdish, V., Madje Balaji, R., and Libale Milind, B., Int. J. Chem. Tech. Res. 2010, Vol.2, No.1, pp. 346-353.

[13] Basheer, K., Muhammad, T.D., Joseph, Joy, and Radhakrishnan, Nair , Indian J. Chem. Sec. A. IJCA 2007,Vol. 46A, 273-275.

[14] Basheer Muhammad, Koottil, Joseph,Joy, and Radhakrishnan, Nair, Modern Research in Catalysis, 2013, No.2, 35-38.

[15] Rahimi Rahmatollah, Zahra, Ghoreishi, Seyyedah, Mohammad, and Dekamin, G., Department of Chemistry Iran University of Science and Technology, Narmark, Tehran, 2010, 16846, 13114, Iran.

[16] Bhatt, D.K., Sherigar, B.S., and Gowda, B.T., Bull. Chem. Soc., Jpn, 1996, 69, 41.

[17] Amis, E.S., Solvent Effect on Reaction Rates and Mechanism, Academic Press, Newyork, 1962, pp. 733.

Citation: Durgesh Kumar Dwivedi et al.. "Study on Oxidation of Benzhydrol and P-Chlorobenzhydrol by Selenium Dioxide: Reaction Kinetics" International Journal of Advanced Research in Chemical Science (IJARCS), vol. 6, no. 1, pp. 1-6, 2019. http://dx.doi.org/10.20431/2349-0403.0602001

Copyright: () 2019 Authors. This is an open-access article distributed under the terms of the Creative Commons Attribution License, which permits unrestricted use, distribution, and reproduction in any medium, provided the original author and source are credited. 